\title{
Mastery of Pedagogical Knowledge and Skills in Technology and Innovation Amongst Army Instructors at Technical Training Centres
}

\author{
Mohd Razdi Omar, Saifullizam Puteh
}

\begin{abstract}
This study examined the mastery of technology and innovation of instructors pertaining to teaching and learning, amongst instructors at Technical Training Centres of the Malaysian Armed Forces (MAF). A study in a form of survey was conducted on instructors in several MAF Training Centres using questionnaire forms. Part of the questionnaire instrument consisted of three parts that were labelled as A (demographics), $B$ (measurement of pedagogical knowledge and contents), and $C$ (measurement of communication, management, and teaching skills in classes and workshops). The sample involved 195 teaching instructors (161 male and 34 female). This study used descriptive statistics to obtain mean (M) and standard deviation (SD) values. The analysis of the results showed that the levels of knowledge $(M=2.10, S D=0.04)$ and skills $(M=2.11, S D=$ 0.32) were low. Based on the study findings, several measures need to be implemented to improve the mastery of the knowledge and teaching skills amongst teaching instructors at Technical Training Centres, to improve the technological and innovation knowledge in teaching and learning. Therefore, more in-depth studies should be conducted in an effort to identify the actions and training that need to be implemented by the MAF management to improve the professionalism of the technical teaching instructors at the Technical Training Centres of the MAF.
\end{abstract}

Index Terms: Pedagogy, Teaching and Learning, Teaching Technology and Innovation, Technical Training Centres.

\section{INTRODUCTION}

The MAF is the fortress of national defense responsible to ensure Malaysia is hindered from all external threats, whether from land, sea, and air, in helping the public authorities in addressing internal threats in the country [1]. Advances in defense technology and changes in tactical war has forced the MAF to increase the strength of the defense in sea, land, and air, consistent with the defense technological revolution of the world. The addition of MAF's high-tech assets directly would closely relate to the support and assistance from the MAF Technical Training Centres. The objectives of the MAF Technical Training Centres are to help increase the knowledge and technical skills of MAF

Revised Manuscript Received on September 22, 2019

Mohd Razdi Omar, Faculty of Technical and Vocational Education, University Tun Hussein Onn Malaysia, Parit Raja, 86400 Batu Pahat, Johor, Malaysia,hb150129@siswa.uthm.edu.my

Saifullizam Puteh, Faculty of Technical and Vocational Education, University Tun Hussein Onn Malaysia, Parit Raja, 86400 Batu Pahat, Johor, Malaysia, saifull@uthm.edu.my members in using high-tech equipment; in order to achieve these objectives, one requires training in theory and in practice [1]. Hence, it is important for MAF to establish Technical Training Centres to train engineers and technicians to ensure assets preparedness levels are at their maximum.

There have been tremendous changes in MAF in the education sector, and MAF is experiencing positive reform. One of the reforms, the integration of a variety of mediums of technology in the teaching and learning process, could help trainers increase the interests and comprehensions of trainees in learning [10]. Teaching instructors is an essential requirement in human resources. Experienced and skilled technical personnel as teaching instructors would enable MAF to achieve its prescribed vision, and would mobilise the existing assets. The teaching and learning by instructors is an important aspect and has the most potential to improve the knowledge and skills which [12], in turn, would lead to the improvement of team and members commitment towards the goals of MAF.

\section{PROBLEM BACKGROUND}

The MAF needs to be in snyc with the development of the education and technical training system towards the industrial revolution 4.0, as proposed by the Government for the military personnel to be always willing to equip themselves with various additional knowledge and skills. The 21st century skills [17] consistent with the expansion of the industrial revolution 4.0 would add values to members of the MAF to enable them to compete in the real working world in units and upon completion of the services [2].

Proven success achieved by MAF in military operations within the country and abroad using the MAF assets indicated that the country is experiencing rapid growth in terms of the use of defence technology presently [3]. Dependency on technology use from abroad led to huge advantages to the country, especially MAF. Among the advantages in terms of information technology, the military could produce members who are capable of using the assets of the MAF and exchangeing information with foreign countries, such as education, technology, and many others. 
The importance of the use of information technology at present is to strengthen the use of technology in the process of teaching, so that the instructors understand any concept to integrate the use of technology in a form that could be understood by students [4]. In this study, researchers paid attention to the problems faced by instructors teaching in the Technical Training Centres.

The Technical Training Centres provide skilled manpower of defense requirements, which consist of $70 \%$ element of vocational training and $30 \%$ of theory learning [9]. The programmes offered at the Technical Training Centres areconsistent with the call by Minister of Defense that the MAF always place education as an important agenda to improve the academic achievement and skills of its members. Education is a holistic and integrated ongoing process to develop the potentials of individuals towards academic excellence, and to acquire a variety of skills, consistent with the Government intention to produce a generation that is competent and competitive at the global level [16]. It is also consistent with the national goals to produce an excellent, glorious, and distinctive generation in the eyes of the world.

The rapid technological changes demand that trainers always master the teaching and learning to meet the expectation to achieve and realise the objectives of the implementation of the National Education System of the $21^{\text {st }}$ Century (SPN 21), so that all gets the positive maximum education impact, as a whole, which covers the physical, mental, spiritual, and emotional aspects [11]. To support this aim, the Technical Training Centreshave been continuously conducting training education programmes for each instructor to equip them with the teaching and learning knowledge to meet the needs of the Technical Training Centres. The effectiveness of the technical teachers in teaching and learning in terms of teachers' knowledge of teaching technical subjects are very much needed [19]. Continuous trainings ensure that trainers possess the efficiency, comprehension,, and knowledge to implement technical education teaching in accordance with SPN 21 in promoting equality and quality education for all.

The Technological Pedagogical and Content Knowledge (TPACK) Model is the basis for effective teaching using technology for pedagogical techniques to deliver knowledge content in teaching students [5]. TPACK is the basis for effective teaching using technology and requires the understanding of the concept of representation through the use of technology and pedagogical techniques that use technology constructively to deliver content and knowledge about existing knowledge of students [8,14,18]. Many teachers were unable to practise the in practice of teaching, skills in integrating ICT into teaching and learning to understand the csubject contents while teaching students [6]. If technology and innovation are used correctly in the classroom, they could help students learn, how to learn, for they provide the opportunity for students to explore and increase their own knowledge, $\mathrm{s}$ well as, allowing them to take the role of trainers students [6].

\section{METHODS OF STUDY}

In this study, researchers used a quantitative method in the form of survey because the method could measure vast study subjects based on questionnaire provided. Referring to the proposal by [8], the population is made up of respondent trainers with a sample size of 195 out of population size of 235 trainers in the Technical Training Centres. To obtain information, the researcher chooses instruments in the form of a questionnaire to obtain feedback and collect data from the respondents.

The instruments of the questionnaire contain three sections, that are labelled as A, B, and C. Section A was intended to obtain the personal information of trainers, namely, gender, race, age, qualifications, field of teaching, teaching and working experiences. Section B contained 15 questions intended to assess the level of knowledge of pedagogy and the content of teaching mastered by trainers through technology and innovation based teaching and learning in the Technical Training Centres.

Section C contained 15 questions intended to assess the level of communication, management, and teaching skills in classes and workshops, mastered by the trainers through the technology and innovation based teaching and learning in the Technical Training Centres. Items in this section used the 4-point Likert scale, where scale 1 represents ' very low ', scale 2 represents ' Low ', scale 3 represents 'Medium', and scale 4 represents 'High' [15].

\section{DATA ANALYSIS AND FINDINGS}

The data collected through the questionnaires were analysed using descriptive statistics to determine the means and standard deviations. The data collection was started by distributing a set of questionnaires to 195 selected instructors. Once the questionnaires were completed by the instructors, the questionnaires were returned for the process of data analysis. Descriptive statistics were used to provide an overview of the background of the respondents based on frequency analysis, percentages, means, and standard deviations.

\section{A. Responden Demography}

A total of 195 instructors were involved in the study, the findings showed only 161 persons $(82.56 \%)$ were male, and 34 persons $(17.43 \%)$ were female. From the findings, 163 respondents (with percentage of $83.59 \%$ ) were Malay, 20 respondents $(10.26 \%)$ were Chinese, and 12 respondents $(6.15 \%)$ were Indian. Out of the total of 195 instructors, 81 respondents $(41.53 \%)$ were aged between 22 to 25 years, 50 (25.64\%) aged between 26 to 31 years, 30 (15.38\%) aged between 31 to 35 years, $25(12.82 \%)$ aged between 36 to 40 years, and $10(4.62 \%)$ aged 41 years and above. Based on education level, 1 instructor $(0.51 \%)$ was a PHD holder, 30 instructors $(15.38 \%)$ were Masters holders, 100 instructors $(51.28 \%)$ were degree holders, 20 instructors (10.25\%) were university or polytechnic diploma holders, 10 instructors $(5.20 \%)$ were Levels 4 and 5 Skilled Diploma holders, 
10 instructors $(5.20 \%)$ acquired polytechnic certification education, and 24 instructors (12.5\%) possessed levels 2 and 3 Malaysian skilled certificate education.

Teaching in the field among instructors are 27 respondents (12.30\%) taught Hul engineering, 27 respondents (13.85\%) taught Marine engineering, 28 respondents (14.36\%) taught Electronics and Radio Engineering, 25 respondents (12.82\%) taught electrical engineering and weapons, 30 respondents (12.83\%) taught Advanced Expertise Engineering, and 61 respondents (31.28\%) taught other technical areas. While based on teaching experience of the total of 195 respondents, 64 instructors $(32.82 \%)$ had 1 to 5 years experience from , 58 respondents $(29.74 \%)$ had a teaching experience between 6 to 10 years, 47 respondents $(24.10 \%)$ had a teaching experience between 11 to 15 years, and 29 respondents $(14.87 \%$ ) had a teaching experience 16 years and above. Based on the analysis of the working experience period, the finding shows 64 respondents $(32.82 \%)$ had been working between 1 to 5 years, 58 respondents $(29.74 \%)$ between 6 to 10 years, 47 respondents $(24.10 \%)$ working between 11 to 15 years, and 29 respondents (14.87\%) working 16 to 21 years, respectively.

\section{B. Mastery of Teaching Knowledge}

The knowledge of instructors played an important role in the application of technology and innovation in the teaching and learning in order to function well. In this study, knowledge was measured based on two dimensions, namely teaching pedagogy and content. The values of means and standard deviations for the mastery of knowledge of technology and innovation based teaching and learning amongst technical instructors in Technical Training Centres.

Table 1.1 shows the analysis of the mean and standard deviation scores for overall level of mastery of knowledge of pedagogy and the content of teaching and learning instructors. The analysis found the level of mastery of knowledge of pedagogy and the content of teaching was low $(\mathrm{M}=2.10, \mathrm{SD}=0.04)$. This shows that the trainers were had not been applying the technology and innovation based teaching and learning knowledge during the process of teaching at the Technical Training Centres. From the findings, it was found that instructors at the Technical Training Centres lacked in pedagogical training exposure and knowledge related to the contents in the technology and innovation based teaching and learning whilst in classes and workshops.

Table 1. Mastery of Knowledge of Technology and Innovation Based Teaching and Learning

\begin{tabular}{clccc}
\hline Item & Statement & $\begin{array}{c}\text { Mean } \\
\text { (M) }\end{array}$ & $\begin{array}{c}\text { Standard } \\
\text { Deviation } \\
\text { (SD) }\end{array}$ & $\begin{array}{c}\text { Interpretatio } \\
\text { n }\end{array}$ \\
\hline B1 & $\begin{array}{l}\text { Adequate } \\
\text { pedagogy. }\end{array}$ & 2.14 & 1.12 & Low \\
B2 & $\begin{array}{l}\text { Practical } \\
\text { technology in } \\
\text { teaching at }\end{array}$ & 2.07 & 1.06 & Low \\
& & & \\
\end{tabular}

workshops/lab

$\mathrm{s}$

B3 Use of

2.14

1.12

Low

technological

resources in

teaching.

B4 Enhance

trainees'

interests in

learning.

B5 Teaching

control

method.

B6 Reference

resources.

B7 Use of

teaching aids

equipment.

B8 Implementing $2.07 \quad 1.06 \quad$ Low

the evaluation

of teaching and

learning.

B9 Contents of

syllabus.

B10 Teaching

objectives.

B11 The objectives

of the

programmes/c

ourses.

B12 Background of $2.06 \quad 1.05 \quad$ Low

trainees.

B13 Vision and

mission of

Training

Centres.

B14 The needs of $2.06 \quad 1.05 \quad$ Low

the

stakeholders of

the

programmes.

B15 The length of $2.14 \quad 1.12 \quad$ Low

time of

students '

learning based

on the

determined

programme

curriculum.

Overall

$2.10 \quad 0.04$

Low

\section{Mastery Of Teaching Skills}

In this study, the trainers' skills played an important role in the application of technology and innovation in teaching and learning in order to function well. Skills are measured based on three dimension; i.e. communications, management, and teaching in classes/workshops.

Published By:

Blue Eyes Intelligence Engineering 
The measured values of means and standard deviations for skills mastery in the technology and innovation based teaching and learning amongst technical instructors at MAF Technical Training Centres.

Table 1.2, shows the analysis of the mean and standard deviation scores for overall level of mastery of communication, management, and teaching skills in teaching and learning classes/workshops of instructors. The analysis found the level of skill was low $(\mathrm{M}=2.11, \mathrm{SD}=$ 0.32). This show the trainers did not quite apply technology and innovation skills in teaching and learning at the Technical Training Centres. Technical Training Centres results of the findings indicated that instructors in the Technical Training Centres were less exposed to in communication skills training, management, and related knowledge pertaining to teaching in technology and innovation based teaching and learning while in classes and workshops.

Table 2. Mastery of Skills of Technology and Innovation Based Teaching and Learning

\begin{tabular}{|c|c|c|c|c|}
\hline Item & Statement & $\begin{array}{c}\text { Mean } \\
(\mathbf{M})\end{array}$ & $\begin{array}{l}\text { Standard } \\
\text { Deviation } \\
\text { (SD) }\end{array}$ & $\begin{array}{c}\text { Interpretatio } \\
\mathbf{n}\end{array}$ \\
\hline $\mathrm{C} 1$ & $\begin{array}{l}\text { Explain } \\
\text { technological } \\
\text { equipment for } \\
\text { RMN assets. }\end{array}$ & 2.13 & 1.11 & Low \\
\hline $\mathrm{C} 2$ & $\begin{array}{l}\text { Vary tests for } \\
\text { assessing the } \\
\text { achievement of } \\
\text { trainees. }\end{array}$ & 2.07 & 1.06 & Low \\
\hline C3 & $\begin{array}{l}\text { Control the } \\
\text { learning } \\
\text { ambiance of } \\
\text { trainees in } \\
\text { technology } \\
\text { classes and } \\
\text { workshops. }\end{array}$ & 2.13 & 1.11 & Low \\
\hline $\mathrm{C} 4$ & $\begin{array}{l}\text { Use technology } \\
\text { equipment } \\
\text { assets of the } \\
\text { RMN. }\end{array}$ & 2.08 & 1.06 & Low \\
\hline $\mathrm{C} 5$ & $\begin{array}{l}\text { Manage } \\
\text { technology } \\
\text { equipment } \\
\text { assets of the } \\
\text { RMN. }\end{array}$ & 2.14 & 1.12 & Low \\
\hline C6 & $\begin{array}{l}\text { Prepare } \\
\text { teaching plans. }\end{array}$ & 2.07 & 1.06 & Low \\
\hline $\mathrm{C} 7$ & $\begin{array}{l}\text { Prepare Test } \\
\text { Determination } \\
\text { Schedule. }\end{array}$ & 2.13 & 1.11 & Low \\
\hline $\mathrm{C} 8$ & $\begin{array}{l}\text { Manage } \\
\text { trainees } \\
\text { information }\end{array}$ & 2.07 & 1.06 & Low \\
\hline C9 & $\begin{array}{l}\text { Manage } \\
\text { working time. }\end{array}$ & 2.12 & 1.11 & Low \\
\hline $\mathrm{C} 10$ & $\begin{array}{l}\text { Managing the } \\
\text { safety of }\end{array}$ & 2.08 & 1.06 & Low \\
\hline
\end{tabular}

trainees in the

classroom and

technology

workshops.

C11 Communicate with trainees.

C12 Implement the $2.06 \quad 1.05 \quad$ Low

Teaching and

Learning

activities

which motivate

trainees.

C13 Oversee

$2.13 \quad 1.11 \quad$ Low

trainee project

development.

C14 Share

information

through

various media.

C15 Use English or $2.13 \quad 1.12 \quad$ Low other foreign

languages

other than

Bahasa

Malaysia.

Overall

2.1

0.32

\section{DISCUSSIONS}

The results of the study findings show that knowledge and skills are essential factors in determining the achievement of trainers in mastering technology and innovation based teaching and learning. The study found that the 195 instructors of MAF Technical Training Centres involved in the study lacked in satisfactory knowledge and skills in the 15 components of the study.

This matter was attributed to no emphasis on approval, experience, and interest of trainers to fill staffing vacancies in Technical Training Centres. An improvement in knowledge and technology should be undertaken by teachers because the ability of teachers to troubleshoot problems depends on their abilities as facilitators, problem solvers, catalysts, and drivers of learning [19].

Refering to Table 1.1, items 1 to 6 indicated the level of the pedagogical approach mastered by trainers were lacking with regards to the knowledge of using various teaching methods to attract the interests of trainees on the courses undertaken. This showed that the training centre did not expose trainers to knowledge of pedagogy by carrying out teaching's courses.

Efforts should be undertaken by each instructor to ensure that trainee interests are always maintained and increased by diversification of teaching methods in classes and workshops. Teachers entering classrooms and workshops with only showing video shows were considered boring, although the method involved high technology [10].

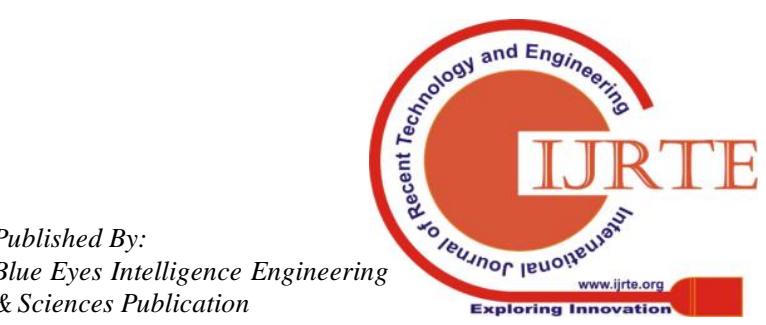


Therefore, instructors need to think of new pedagogical methods and diversify the same, so that the trainees will not be easily bored with the same method, notwithstanding that a video show is a fun method. The emphasis should be to maintain and increase the interest of students to continuously learn [13].

Instructors should comprehend fully the change ideas and strategise impecably to ensure successful implementation. To address changes in innovation in the teaching and learning, instructors need to master the ever changing technology as well as gain further knowledge.

The level of knowledge of the contents of teaching amongst instructors in the Technical Training Centres is reduced. Based on Table 1.1, for items 1 to 9, there was a lack of knowledge of the content of the elements of syllabus, teaching objectives, programmes, vision, and mission of the training centres in technology and innovation based teaching and learning. Teachers' comprehension of the topics to be taught helped teachers to prepare teaching lessons in terms of approaches, methods, techniques, and teaching strategies [6].

Instructors indeed had high comprehension of the pedagogical knowledge and teaching contents because they went through practical training in stages during the teaching course. This indicated that the emphasis on basic knowledge of the contents of teaching to appointed instructors was not done at Technical Training Centres.

Teachers acquire basic knowledge either as students or through formal education training. However, it is undeniable that experience also contributes e a big role of teaching in schools (Edros, 2007). As such, Technical Training Centres need to conduct an instructor education programme to trainers who specialises in one field to allow them to be more focused on pedagogical knowledge like experienced instructors.

Referring to Table 1.2, items 1 to 4 show the level of mastery of teaching skills in classes/workshops was reduced. Teaching deficiency in classes/workshops in the skill elements were technology equipment, trainer performance assessment, learning environment, and use of equipment. The failure to use teaching aids was attributed to insufficient numbers of equipments, unstrategic and uncoordinated storage location, teachers lacking the time to prepare for it, teachers were not creative in teaching, and teachers not proficient in the use of technology equipment teaching aids (Rashid, 2007).

The level of management within the Technical Training Centres was lacking based on Table 1.2 for items 5 to 10 . The management lacked in skills elements, which were technology equipment, teaching plan, trainees' information and safety. Teachers need to be skillful in management skills by using a variety of methods and techniques of teaching to avoid boredoom in trainees and to make effective teaching (Mahamud, 2009).

In addition, the level of communications in trainers' teaching at Technical Training Centres was insufficient based on Table 1.2 for items 11 to 15 . The lack of communication in the skills element was trainee motivational activities, trainee project development, information sharing, and the use of language in teaching. The communication skills used by teachers were closely linked/related to students' understanding to accept teachers' teaching and were the platform to ensure the effectiveness of teachers in conducting the teaching and learning (Hashim \& Phang, 2017).

\section{CONCLUSIONS}

The findings of this study showed that the level of knowledge and teaching skills amongst trainers in Technical Training Centres were at a low level. Therefore, instructors should strive more to strengthen professionalism by being more creative and open in improving the performance of trainees. Self improvement needs to be done on an ongoing basis amongst trainers so that education objectives are achieved as stated in MAF plans.

\section{ACKNOWLEDGMENTS:}

The author would like to thank to Malaysian Ministry of Education (MOE), Faculty of Technical and Vocational Education, Universiti Tun Hussein Onn Malaysia (UTHM) and Malaysian Armed Forces for supporting this research.

\section{REFERENCES}

[1] Ahmad, I. (2009). Current army procurement Practices and their impacts on the preparedness of Materials an analysis. Retrieved from http://www.pendeta.um.edu.my/uhtbin/cgisirsi/x/

[2] Amran, N \& Rosli, R. (2017). Teachers' Comprehension of 21 st Century Skills. Date October 31, 2017. Retrieved from http://conference.kuis.edu.my/pasak2017

[3] Bakar, R. (2005). Malaysian roles in the peacekeepers teams of the United Nations. Universiti Malayar Retrieved from http://www.pendeta.um.edu.my/uhtbin/cgisirsi/x/

[4] Edros, S. N. (2007, November). The Construction Of Tutorial Using Interactive Graphic Softwares . Retrieved from http://eprints.utm.my/6580/

[5] Hashim, Z \& Phang, F.A (2013). Pedagogical Technological Knowledge Practices for Form Six's Physics Teachers Content. Accessed on November 3 2017. Retrieved from http://educ.utm.my/wpcontent/uploads/2013

[6] Hashim, Z \& Phang, F.A (2017). Comparison Of Factors Influencing Teaching And Learning Processes Between Schools In Urban And Rural Areas.

[7] Hassan, N.F., Puteh, S. (2017). A survey of technology enabled active learning in teaching and learning practices to enhance the quality of engineering students. Advanced Science Letters, 23 (2), pp. 1104-1108.

[8] Hassan, N.F.B., Puteh, S.B., Muhamad Sanusi, A.B. (2018). Elements of Technology Enabled/Enhanced Active Learning (TEAL) to Enhance Quality and Employability of Bachelor's Students. MATEC Web of Conferences, 150, art. no. 05005.

[9] Jamaludin, K. R. (2004). Diploma of Technology: A New Sheet For Training Towards Producing Corps Of Engineers. Retrieved from http://eprints.utm.my/482/

[10] Malik, N. (2013, January). The application of characteristics of effective teachers in the teaching and learning process during teaching practice among postgraduates of UTHM. Universiti Tun Hussein Onn Malaysia. Retrieved from http://eprints.uthm.edu.my/4186/

[11] Mahamud, M. R. (2009, July). The subjects of Islamic Education and its impact on the increase in Student Discipline: a study in Secondary Schools in Perlis (phd). USM. Retrieved from http://eprints.usm.my/28703/

[12] Mohamad Zahid, N.H.C., Hanafi, N.M., Puteh, S. (2017). Instructional rubrics as an alternative approach for improving practical teaching among teachers candidate. Advanced Science Letters, 23 (2), pp. 1229-1233. 
[13] Magdeline \& Zamri, (2014). Influence of Social Factors In Malay Languange Learning Among Iban Students. Retrieved from http://journalarticle.ukm.my/10415/1/135-260-1

[14] Puteh, S., Maisarah, M., Rosnawati, B.(2017). Employability skills mastery of special needs students at polytechnics. Pertanika Journal of Social Sciences and Humanities, 25 (May), pp. 41-46.

[15] Riduwa, (2012). The Relationship Between Knowledge and Communicative Practice Among Teachers Of Malay Language. University Kebangsaan Malaysia.

[16] Rashid, R. (2007, November). The relationship between learning styles and motivation among students at a secondary school in a rural area, Sabah (Masters). Universiti Teknologi Malaysia, Faculty of Education. Retrieved from http://eprints.utm.my/6527/

[17] Salleh, N.N.H.M., Puteh, S. (2017). A review of the 21 st century skills in technical vocational education and training (TVET). Advanced Science Letters, 23 (2), pp. 1225-1228.

[18] Sanusi, A.M., Puteh, S. (2017). An approach of excellence talent in engineering education programme of enhancing the quality of students. Advanced Science Letters, 23 (2), pp. 1109-1112.

[19] Yahaya, A., Mohd Nor, R., Ismail, S., \& Abdul, A. H. (2010). The Effectiveness Of Teaching And Learning Among Teachers Of Technical Subjects. The effectiveness of teaching and learning among teachers of Technical Subjects $1-12$

\section{AUTHORS PROFILE}

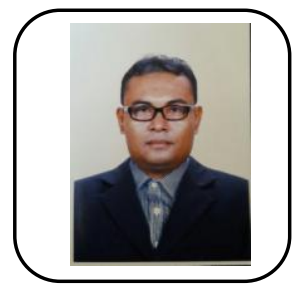

Mohd Razdi Omar, I am postgraduate student in the Faculty of Technical and Vocational Education, in Universiti Tun Hussein Onn Malaysia and specialize in Technology Innovation in TVET. In my research, I tend to examine the mastery of pedagogical knowledge and skills in technology and innovation amongst army instructors at Technical Training Centres. I have Bachelor of Electronic and Telecommunications Engineering with Honours at Universiti Malaysia Sarawak. Based on my experience, I am a retired as NAVY officer as engineer (2000 to 2013), and have work experienced at Halim Rashid Holding engineer (2014 to 2016).

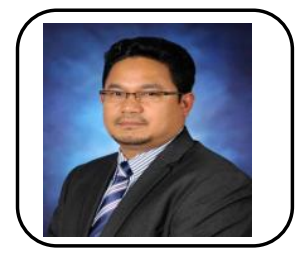

Saifullizam Puteh, I am an Associate Professor in the Faculty of Technical and Vocational Education, Universiti Tun Hussein Onn Malaysia. Based on the duties and experience, I am interested in sharing knowledge and skills to the group in the field of TVET educators and Industrial Instructor, to help improve the competencies of technological Pedagogical Knowledge. My research interests focus on two related areas. The first is the Innovation and Technology Education in TVET. I continue to be interested in Technology Enhanced Active Learning in TVET. I am also interested in technical such as Computational Intelligence and Electrical and Electronic Engineering. 